Article

\title{
NEITHER BITCH NOR MOTHER: QUEERING SAFETY IN THE CLASSROOM
}

\author{
CATHERINE O. FOX \\ Associate Professor, St. Cloud State University, St. Cloud, Minnesota \\ cofox@stcloudstate.edu
}

\begin{abstract}
Reciprocity between teachers and students has been central to transformative pedagogies since the early work of Paulo Freire. However, realizing students as knowledge-producers is much more difficult. This article argues that typically it is the critical educator who "troubles" students' ideological assumptions, often with the aim of culturally reproducing ourselves through what Michael Warner describes as reprosexuality. This places teachers at the center of the power/knowledge nexus and can foreclose the possibility of a dialogic relation with students in which the power of knowledge-making is a shared endeavor. Using a case study of a graduate course focused on feminist rhetorics and pedagogies in which maternal nurturance and safety in the classroom were central issues, this article explores how Judith Butler's politics of recognition and vulnerability can serve to build truly reciprocal studentteacher relations and a renewed vision of the role of safety in the classroom.
\end{abstract}

\section{Key Words}

Queer theory, Safety, Feminism, Reciprocity, Pedagogy

\section{Biography}

Catherine O. Fox is an Associate Professor at St. Cloud State University in St. Cloud, Minnesota. She teaches in the undergraduate and graduate programs in Rhetoric and Writing and her work focuses on the intersections of rhetoric, feminism, and queer theory. Her work has appeared in the journals Feminist Studies, College English, Pedagogy, JAC: Journal of Rhetoric, Culture, and Politics, and Third-Space.

Transgressive pedagogies originating from Lesbian, Gay, Bisexual, Transgender (LGBT) communities can be categorized into two general trajectories: one operates from an identity based, inclusion model, the other operates from queer theory and seeks to disrupt normative categories, practices, and ways of knowing and being in the world. Being identified as a queer educator is not synonymous with an LGBT identity, although 
certainly being positioned differently in relation to heteronormativity ${ }^{1}$ provides a locus of interest in queering the classroom. Instead of focusing on homophobia or heterosexism as the site of violence (whether physical or psychological/emotional), queer studies employs "queer" as "a term defined against 'normal' and generated precisely in the context of terror - [the term] has the effect of pointing out a wide field of normalization, rather than simple intolerance, as the site of violence" (Warner 1991, 16). For example, theorizing a performative pedagogy and its relationship to LGBT people, Karen Kopelson (2002) traces scholarship in writing pedagogies that operates from an inclusion model and argues that the arc of this approach generally seeks "to determine what classroom conditions and pedagogical approaches might best facilitate the comfort, safety, and optimal learning situations for lesbian and gay students themselves, so that they might 'come to voice' as writers" (18). Centralizing homophobia, Kopelson contends, leads to "personalizing and pathologizing the fear of homosexuality, rather than uncovering homophobia's implication in - its wholesale dependence upon-pervasive systemic heterosexism and heteronormativity" (20). Such pathologizing discourses, according to Kopelson, operate "only from the point of view of the one who fears, thus ultimately validating the fear itself, and recuperating (a doubting and squeamish) heterosexuality as norm" (20). Queer pedagogy has typically been considered more "transgressive" than identity based pedagogies insofar as it focuses on the root of social inequities and oppressions (fields of normalization) with the hope of complicating the ways we think, operate, and relate in and with the world that surrounds us rather than seeking to expand existing social relations and practices to be more inclusive.

Since the beginning of my career nearly fifteen years ago I have sought to "queer" two primary assumptions that circulate in conversations about radical pedagogies, particularly feminist pedagogies: that female professors espouse a collaborative, caring, maternal relation to students and that part of this "maternal care" entails creating the conditions for safe interchange in the classroom (Noddings 1984). Within conversations about feminist pedagogy the assumption that women are naturally inclined towards caring, collaborative, nurturing relationships has been a centerpiece to conversations about what distinguishes a feminist pedagogy from other pedagogical approaches. Beyond the fact that such a normalized role essentializes female professors and ignores how some women (for example, black women in the context of the United States) have been expected to care for those in the dominant class in ways that recuperate privilege and power along lines of race and class, there have been several other lines of critique that problematize these assumptions. Andrea Greenbaum (2002) examines how female

\footnotetext{
${ }^{1}$ Heteronormativity refers to the interconnecting system of norms used to create social order. It places people into two distinct genders that are linked to biology (men are masculine and women are feminine) and holds heterosexuality as normal, natural, and inevitable, which effectively marginalizes and stigmatizes other forms of sexuality and gender.
} 
professors who resist taking on a maternal role in the classroom often are evaluated poorly in student evaluations as well in annual professional review documents and promotion and tenure processes. Women are granted a certain degree of authority in the classroom to the extent that we espouse "legitimate" roles; those who challenge the norm are left bearing the negative consequences, leaving many female teachers in a double-bind that makes it questionable whether such a role should be considered a defining characteristic of feminist pedagogies. In arguing for conflict as central to a feminist pedagogical approach, Susan Jarratt (2003) interrogates the ways in which the assumption that feminist teachers take on a maternal role represents an essentializing tendency that reproduces both the exploitation and devaluation of women's labor and ignores the complexity of subject positions women (and men) occupy. This perpetuates the norm of the self-sacrificing woman and can undermine the agency of female teachers to assert authority in non-normative ways. Finally, furthering a critique of how an ethic of maternal care reproduces dominant social relations, Bernice Fisher (2001) argues that

The mothering model...valorizes asymmetric social relations... What the ethic of care takes to be reciprocity (the baby's smile, the student's moment of understanding) is not true reciprocity. In contrast to egalitarian relationships such as friendship, 'caring' interactions do not include the carer's needs in the picture. They do not require the cared-for to see the person who is attending to her from the latter's point of view (125).

Maternal nurturance is wrought with complications and there are no guarantees that it will lead to transformative relations; yet, neither is it transgressive to simply not care and foster students' development. Furthermore, students will "read and write" us with the available scripts no matter how we might believe we are challenging normative roles and relations. Thus it is a complex role and expectation that must be negotiated as we manage the meanings is has for our students as well as ourselves. ${ }^{2}$

The notion that female teachers take on nurturing, caring, maternal relations to their students has worked in tandem with assumptions that classrooms should be

\footnotetext{
${ }^{2}$ In a recent conversation about this article with a graduate student who has been in several of my classes, including the Feminist Rhetorics and Pedagogies course, and who finds a similar limitation in role of being a female coach: either you are a bitch or a mother, we were discussing student perceptions of my teaching style and limitations in metaphors used to describe women in leadership positions. She suggested that students perceive me as "scary, but approachable" and what marks my style of interaction with students is the fact that I do not attempt to be-friend students nor act like a maternal figure, instead, she said, "We see you as this person that you want to work really hard for because it benefits us to be challenged." What I found most interesting is how devoid our language is of positive metaphors for assertive women in leadership. Without a language we are terribly limited in how we imagine ourselves and others.
} 
configured as safe spaces. This idea has been particularly dominant in research and teaching about LGBT students since the advent of the Gay Lesbian Straight Education Network (GLSEN) Safe Space program in the 1990s. Through on-site trainings and the display of "safe zone" stickers on faculty and classroom doors, this program seeks to create visibility and educational programs on college campuses for LGBT students as a way of countering the violence of homophobia, heterosexism and transphobia. LGBT students tend to have higher rates of depression, substance abuse, social isolation and failure in school or work (Brown and Happold 2002; Rankin 2004) and much positive work has been accomplished in raising awareness and addressing the physical and emotional violence that has affected LGBT peoples' sense of self-esteem and success in institutions of higher education. Certainly we do not have to dig very deep into the news to find increased reports of violence in schools in the form of bullying those who fail to conform to gender and (hetero) sexuality norms. ${ }^{3}$

While laudable in its efforts to educate both teachers and students about the violent effects of various isms that impact LGBT people, I have always found myself at odds with the very notion that the classroom can or should be a safe place. In my early years of teaching I recall conversations with colleagues who identified as allies and spoke of the ways in which they establish their classrooms as "safe spaces": places LGBT students could expect to be free from anti-gay bias and homophobia. I was always taken aback by these conversations, in part because I espouse Stuart Hall's (1996) sense that there are "no guarantees" in either hegemonic or counter-hegemonic struggles for power, and in part because such an approach suggests that the teacher can single-handedly mold the fluid, dynamic nature of a classroom into a safe space for those who might be identified as queer or identified as marginalized in other ways. Heteronormativity is partially constructed through a dichotomous logic, where heterosexuality is considered normal, natural, and inevitable and homosexuality is constructed as its binary opposite: abnormal and perverse. Elsewhere, I have argued that discourses of safe spaces for LGBT students too often reproduce this dichotomy through an inclusion model that focuses on homophobia (Fox 2007). Suggesting that allies give, provide, offer, and secure safe space for LGBT people reinforces the normative authority and power of an ally to be the agent configuring what these spaces might be. While the inclusion model has been an important part of development towards queer studies over the last thirty years, it tends to focus on visibility and countering homophobia and often revolves around how to help LGBT people feel comfortable within existing frameworks rather than disrupting them. The display of safe space signs, however well-intentioned, often operates through a

\footnotetext{
${ }^{3}$ It seems particularly noteworthy that ten teenagers in the United States chose to take their lives after persistent bullying from peers (Billy Lucas, from Indiana, Tyler Clementi from New Jersey, Cody Barker from Wisconsin, Asher Brown from Texas, Seth Walsh from Indiana, Harrison Chase Brown from Colorado, Alec Henrikson from Indiana, Raymond Chase from Rhode Island, Felix Sacco from Massachusetts, and Caleb Nolt from Indiana).
} 
transactional rather than transformative logic that serves protect the social safety (or comfort) of allies, thereby occluding genuine reflection, dialogue, and struggle about what might constitute safety for marginalized peoples.

Another problem in discourses of LGBT safe spaces is the conflation of safety with comfort within LGBT campus communities. The conflation of safety and comfort also reproduces relations of power and privilege by failing to address the normalization of maleness and whiteness in the context of what constitutes an LGBT safe space (Fox 2010). Again, at work in the reproduction of these gender and racial norms is the maintenance of social safety, or comfort, for centered subjects in which they can exist in a place of ignorance.

Power dynamics in classrooms (and other social contexts) are fluid rather than fixed and neatly correlated to particular identities. For example, within queer cultures there is the phenomenon of "guilt by association," which takes on a unique valence in the classroom when the teacher is out or otherwise visible as queer such that LGBT students might feel more "unsafe" for fear of being identified as queer through some sort of affinity with the professor or through being "outed" by the professor. Thus, as a queer educator I understand that my choice to be out in the classroom can oftentimes render that space more rather than less safe for similarly identified students. Ultimately, the assumption that one can create "safe spaces" for those who are "othered" within various fields of normalization is born of a kind of willful ignorance and re-instantiates relations of power and privilege. ${ }^{4}$

\section{“Troubling” Maternal Nurturance and Safety}

Every two or three years I have the privilege of teaching a graduate course on the topic of feminist rhetorics and pedagogies through our Rhetoric and Writing Master's program. Typically the course draws graduate teaching assistants who are teaching FirstYear Composition as well as secondary school teachers seeking advanced educational credits. Invariably the topics of maternal nurturance and safety arise around the content of the course as well as my style of teaching. One particular strand of our conversations tends to be organized around Sally Miller Gearhart's (1979) argument that persuasion, insofar as it is embedded in a desire to change people, is an act of control and domination. Sonja Foss and Cindy Griffin (1995) take up Gearhart's original argument and forward the concept of invitational rhetoric, which suggests that feminist discourse should be organized around respectful "offering" rather than agnostic competition and devaluing the perspectives and opinions of others. Graduate students are very drawn to

\footnotetext{
${ }^{4}$ Mumbi Mwangi and Kyoko Kishimoto (2009) have also problematized the role of safety in feminist classrooms where faculty of color teaching a largely white student population are consistently faced with a hostile academic climate.
} 
invitational rhetoric, in no small part, I believe, because graduate school can be a painful and humiliating experience as they negotiate the very real tensions of power and knowledge in the context of an advanced professional degree, but also because many of the graduate students I teach are teaching or tutoring writing for the first time and are attuned to power dynamics in their own classrooms as a result of their dual position as both instructors and students. We also read pieces by bell hooks (1994), Susan Jarratt, (2000; 2003) and Andrea Greenbaum (2002), all of whom articulate the place and value of conflict in a feminist pedagogy; very seldom are students drawn to these ideas as they are to the concept of invitational rhetoric. Time and again, they insist classrooms should be safe places in which students feel nurtured and cared for.

Attempting to "trouble" ${ }^{5}$ these assumptions, I encourage students to examine how naturalizing female teachers as maternal creators of safety serves to reproduce normalized social relations that does little to create transformation. Presenting my argument about safety-that it is often equated with comfort, particularly maintaining the social comfort of those in privileged positions and the idea that classrooms can never be entirely safe (nor should they be because I believe we learn best in edgy, risky situations) - unsettles students' basic assumptions about transformative pedagogies. More often than not, safety in the classroom is understood through a binary logic: if we are not creating safe places, then we are necessarily creating dangerous places. This fixed notion of safety occludes how safety is a process that we engage in daily rather than a product that we produce de facto by making broad declarations about classroom climate or prohibited language (such as homophobic, racist, or sexist comments). A process approach requires that we surrender ourselves to the ineffable: embracing that we cannot know in advance the complexity of subjectivities and histories that collide and combine in any particular pedagogical situation. This unknowingness does not mean we abandon efforts to create safety, but it does require that we complicate our thinking about what safety is and how it can be developed in such a way that disrupts normative, reproductive relations.

Not surprisingly, students are initially jolted by my stance in relation to safety and maternal nurturance, and although I push students to "queer" normative roles and relations, there is a certain degree of playfulness in expanding our imaginations and exploring alternatives. Indeed, over the course presenting these ideas to several different

\footnotetext{
${ }^{5}$ The term trouble refers to Butler's book, Gender Trouble (1999), and her argument that understanding gender as a construct does not undermine feminist politics; instead, creating "gender trouble" can be a way of interrupting normalizing tendencies that link sex, gender and desire in ways that are limiting and oppressive. Butler explains, "To make trouble was, within the reigning discourse of my childhood, something one should never do precisely because that would get one in trouble. The rebellion and its reprimand seemed to be caught up in the same terms, a phenomenon that gave rise to my first critical insight into the subtle ruse of power: the prevailing law threatened one with trouble, even put one in trouble, all to keep one out of trouble. Hence, I concluded that trouble is inevitable and the task, how best to make it, what best way to be in it" (xxvii).
} 
groups of students in my Feminist Rhetorics and Pedagogies course I have found that this topic proves to create lively and engaging conversations that extend well beyond the frame of any given semester. For example, one student took on the topic of mothering and safety for her thesis project and searched for alternative metaphors for the role of female teachers. Several students grappled with what it might mean for male students to "mother" their students and how this might queer student-teacher relations. Another student came upon a metaphor borrowed from the heavy metal band, Iron Maiden. After graduating she sent me a t-shirt with the band's logo that still hangs on my office wall. Being somewhat illiterate about pop culture, I cannot speak to contradictions in correlating this band to feminist pedagogy, but the t-shirt reminds me of how students genuinely reached for new ideas about maternal metaphors even as they held fast to assumptions about safety (which indicated to me the "normative" status of the concept). Following Andrea Greenbaum's work on "bitch pedagogy," another student suggested that instead of thinking about either being a bitch or a mother in the classroom, they could think of new roles, such as one he playfully ascribed to me: "the mother of all bitches." This particular reading of my teaching style (which I believe can extend to other female professors who do not identify as "mothers" in the classroom) has always intrigued me because it points to how few positive metaphors are available for representing strong, assertive females in leadership positions. ${ }^{6}$

\section{Whose Trouble?}

I have held fast to the belief that classrooms can never be totally safe and I admit that I take some pleasure in troubling my students' normative assumptions. And although I make space for my students' perceptions in classroom conversations, by in large I thought they were simply naïve. However, it is they who have the last laugh, as it were. "How can you say you do not believe safety is possible in the classroom, Catherine," they demand, "when we feel nurtured and safe in your classroom?" The first time students told me this I wondered, with irony and humor of course, what am I doing wrong that my students feel safe in my classroom? Having spent a good portion of my professional career critiquing notions of safety, I was "troubled" to be presented with a reading of my teaching style and personality at odds with both my published arguments as well as my self-perception.

Reflecting on how adamantly I clung to my beliefs I began to wonder to what extent reprosexuality was at work in my teaching, which Michael Warner (1991) describes as "the interweaving of heterosexuality, biological reproduction, cultural

\footnotetext{
${ }^{6}$ Some students have suggested using the metaphor of an "aunt" or "extended family member," yet this strikes me as operating within a heteronormative framework in which biological kin are thought to constitute our most meaningful relations.
} 
reproduction... Reprosexuality involves more than reproducing, more even than compulsory heterosexuality; it involves a relation to self that finds its proper temporality and fulfillment in generational transmission" (9). Reprosexuality, like heteronormativity, is grounded in the notion that heterosexual family and kinship structures connote our most meaningful interaction and lived experiences. This is a particularly useful concept to use in thinking about graduate education in which a parent-child relationship becomes a vehicle through which we culturally reproduce ourselves and our program identities in students, thus attempting to ensure generational succession. Like most professors who teach about and embody a transgressive pedagogy, I have tended to conceive of myself as one who resists the kind of reprosexuality organized around cultural reproduction and generational transmission that Warner describes; however, through years of interactions with graduate students I have begun to question to what extent I have sought to pass on my beliefs or culturally reproduce myself in my unyielding arguments about safety and maternal nurturance and my unwillingness to seriously consider their perceptions of safety.

Indeed, creating "trouble" is productive only insofar as the lines of critique about our assumptions and beliefs lead us to imagine new possibilities. Unfortunately, as transgressive educators we often think of ourselves as creating trouble for our students rather than them troubling us. ${ }^{7}$ In the tradition of Paulo Freire (1970), it seems that for a pedagogy to be truly transgressive it must be founded in reciprocity: teachers teach students, students teach teachers, and students teach students. This is a radical concept, one that seems to get at the roots of inequity in teaching and learning relationships. ${ }^{8}$

\footnotetext{
${ }^{7}$ This is, of course, is an issue of power. I am not suggesting that students do not wield power in the classroom. I use "trouble" in the tradition of queer theory which implies a critique of normativity rather than a reproduction of normativity along lines of race, class, gender, and sexuality. Scholars such as Roxana Ng (1993), Himani Bannerji (1995), and Mumbi Mwangi and Kyoko Kishimoto (2009) have articulated the need to account for the location and subjective positions of faculty of color teaching in predominantly white institutions who often face hostility in the classroom through explicit verbal attacks or less explicit forms of hostility, such as persistent demands to justify and defend their knowledge and teaching practices. As an out lesbian who does not conform to a normative feminine gender performance I have also experienced the exertion of power from students who relentlessly disrupt the classroom in efforts to reassert privilege and power from a normative position. One student went so far as to stalk me with threatening emails over a course of many years. And, parallel to the experience of faculty of color in predominantly white institutions, the administrative response has typically ignored acts of hostility towards me and questioned what I do in the classroom that leads to "conflict" with students. My supposed "inability to manage classroom conflict" and the advice to "acquire a senior teaching mentor" who instruct me in more "productive teaching techniques" was documented and filed in my personnel file for years preceding tenure and promotion. As Roxana $\mathrm{Ng}$ points out in parallel administrative responses to complaints from students, it had "less to do with my competence as a teacher that with who I am" (190).

${ }^{8}$ Incidentally, I do not believe there is anything terribly transgressive if this reciprocity is reduced to questions about how students can teach us to better "deliver" the content of our courses. This does little to
} 
Of course, reciprocity is based on Freire's work with adult students and a sense of mutual respect between both parties. Oftentimes this sort of reciprocity seems more achievable in the context of either graduate education where students are older and more mature or in the context of teaching non-traditionally aged undergraduate students because of maturity levels and lived experience. Mutuality in pedagogical situations also brings to the fore issues of power and authority and the ways in which our social positioning in larger structures of race, class, gender, and sexuality (among others) affects the degree to which we are authorized or de-authorized as professionals. As Roxana $\mathrm{Ng}$ so eloquently illustrates in her examination of an incident involving a white male student complaint and an administrator, the institutional response "produced and reinforced [her] position as a gendered and racialized subject in the university" (191), which effectively de-authorized her and re-instantiated power relations and inequities organized around race and gender. Ng contends, "We must develop a critical awareness...of the fact that people participate in institutions as unequal subjects" (199). Indeed, mutuality between teacher and students is neither possible nor desirable in all pedagogical situations precisely because power relations both precede and exceed the microcosm of classrooms.

However, where reciprocity and mutuality in the teaching and learning process is desirable and achievable, it often seems to be embraced as an abstraction rather than a realized practice. Judith Butler's (2004) concept of transformation offers a tool for attuning ourselves to reciprocity in the classroom, or rather, moments where reciprocity has shut down:

To intervene in the name of transformation means precisely to disrupt what has become settled knowledge and knowable reality, and to use, as it were, one's unreality to make an otherwise impossible or illegible claim.... when the unreal lays claim to reality, or enters into its domain, something other than a simple assimilation into prevailing norms can and does take place. The norms themselves can become rattled, display their instability, and become open to resignification (27-28).

While I am not convinced that students' insistence that the classroom be a safe place is exactly the kind of "impossible or illegible claim" that Butler references (because it slides so easily into normative expectations), it certainly rattles my own sense of "settled knowledge." As radical educators we too often become so wedded to our ideas because of a self-perception that we are the ones on the margins of normative discourses; we forget to turn inward and engage in the kind of self-reflexivity that is foundational to 
accountability and social transformation. As mentioned above, I held fast to my belief that teaching and learning can never be completely safe for several years, chalking students' perceptions to inexperience. But the conversations continued-from one year to another they flowed from classroom, to the hallways, to my office. The persistent trouble students presented to my settled knowledge about safety served as a call to pause and consider alternatives.

\section{The Politics of Recognition and Risk}

Butler's work on the paradox of power and what makes for a livable life provides an entry point for understanding my students' sense of safety in the classroom. Exploring questions of who counts as human and whose lives count as grievable lives in the face of increasing violence against those who challenge existing forms of gender driven by transphobia and heteronormativity as well as the increase in anti-Islam violence driven by nationalism and Islamphobia since the events of September 11, Butler (2004; 2005) turns our attention to the limits of autonomy and the politics of vulnerability and recognition. Drawing on her earlier work (1997) on subjectivation and power in which she explores how we are dependent on external power in order to have a sense of self even as this external power becomes a threat to our autonomy, Butler insists that, as social beings, we are never fully autonomous; from the start we are "laid bare," fundamentally dependent on others:

We come into the world unknowing and dependent, and, to a certain degree, we remain that way. We can try, from the point of view of autonomy, to argue with this situation, but we are perhaps foolish, if not dangerous, when we do. Of course, we can say that for some this primary scene is extraordinary, loving, receptive, a warm tissue of relations that support and nurture life in its infancy. For others, this is, however, a scene of abandonment or violence or starvation... No matter what the valence of that scene is, however, the fact remains that infancy constitutes a necessary dependency, one that we never fully leave behind (2004, 23-24).

Following the work of Hegel and Spinoza, Butler argues that, as social beings, this dependency continues throughout our lives through our desire for recognition, which comes primarily through norms. Not insignificantly, Butler insists that not everyone is intelligible as human: "to be called unreal and to have that call, as it were, institutionalized as a form of differential treatment, is to become the other against whom (or against which) the human is made" $(2004,30)$. Thus, our political endeavors must not only involve a struggle for rights that are attached to personhood, they must also involve a 
struggle over the very concept of who is conceived of as "human" in the first place because this is both produced and de-produced through norms of recognition. "If there are no norms of recognition by which we are recognizable," Butler contends, "then it is not possible to persist in one's own being, and we are not possible beings, we have been foreclosed from possibility" $(2004,31)$. Of course there is a tension here because we are both enabled and constricted by norms. For example, normative conceptions of personhood that bifurcate gender and articulate gender to fixed notions of sex and desire undermine the ability for many people to persist meaningfully. ${ }^{9}$ Complicating her earlier work, Butler's more recent work gets to the heart of why it is not enough to simply create gender "trouble" through disruption of norms: whether we like it or not, we are deeply enmeshed with one another, and this interconnection renders us necessarily vulnerable to others.

Butler's exploration of the politics of recognition and our dependency on others resonates with my critiques of safety in educational contexts as well as my students' calls for safe spaces. If we are fundamentally vulnerable through our need for recognition, then it makes sense to both name the world as potentially dangerous even as we make efforts to create the conditions through which we can ameliorate the annihilating effects of being rendered "unrecognizable."

\section{Navigating the Briar Patch: The Only Way Out is Through}

Despite the small opening that Butler's theory provides, I still found myself grasping to my original arguments. Interestingly, the handful of LGBT graduate students with whom I have worked have shared my sense that teaching and learning are necessarily unsafe. Barclay Barrios's (2004) metaphor of the briar patch is instructive here in thinking about a queer relationship to safety, which Barrios offers as a tool to help all students queerly navigate the world:

The briar patch, like the world, is a dangerous place-it is, after all, filled with brambles and that's just what keeps Brer Fox out. What makes it a refuge for Brer Rabbit is not something inherent in its nature but the fact that it's where he was

\footnotetext{
${ }^{9}$ This is particularly true for transgendered people, whose biology does not normatively align to their expression of gender. It is also true for people identified as gender-queer, for example a masculine woman who desires men. Herein lies the usefulness of naming the problem as heteronormativity rather than just heterosexism. Heterosexism suggests that heterosexual relationships are privileged over others. Heteronormativity points to an entire system of linkages (for example, the expectation that we cohabitate with a spouse, we share a surname, we exist in sexual dyads, we have a desire to reproduce, our desire arcs towards an object (man or woman) and particular body parts associated with those objects, our biology determines our gender and our desire, etc.) that serves to control and order expressions of self and desire across all sexualities.
} 
raised. And having been raised there means that he knows how to move through the briar, how to use the thorns to his advantage, how to find his way through the thickets, how to, in short, negotiate its dangers successfully (344).

Barrios' words resonate at the very core of my being: Yes, yes, the world is dangerous, someone else is saying it too-and it is no coincidence that this person is a queer person of color. Violence is not directly evenly at everyone nor is the world equally dangerous to all. How we are multiply-positioned in relation to normative structures of power and privilege influence the our vulnerability to both physical and psychological violence, and thus the degree to which we experience the world as a "briar patch."

As a marginalized community, there is something unique about the experiences of LGBT people who not only find ourselves under attack as a result of restrictive norms around sex/gender/desire from strangers, but quite frequently from those upon whom we are dependent from infancy. Threats of violence and rejection come early in many LGBT peoples' lives, often from our families of origin and our most intimate friends (before we make steps towards a "family of choice"). So many queer people are not formed within a "warm tissue of relations that support and nurture life" (Butler 2004, 23-24) and we learn to protect ourselves from a very early age by disconnecting from some of our most intimate and foundational relationships. Placing this in conversation with Butler's work on our fundamental vulnerability and need for recognition underscores why safety is a terribly complex and complicated issue and clarifies why some LGBT people have centered safety as a core political issue even as others insist that no site or relationship can ever be finally or totally safe.

Of course, it is possible that the conflicting views on safety constitute an impasse caused by social positioning-perhaps those further positioned on the margins are simply oriented to the world differently in ways that those closer to the center cannot understand. ${ }^{10}$ But self-reflexivity calls me to consider how this might be one more way to solidify my established beliefs, to close down the dialogue and rest in my "settled knowledge." I want more from a transgressive pedagogy. It is not enough to simply find confirmation of my ideas in the work of other scholars, like Barrios, and use it to further convince students of the correctness of my position. I want a different relationship to knowledge and teaching, a more expansive, less "reprosexual" relationship with my students that offers new possibilities for imagining how we might relate to one another.

When we are called to consider how our social positioning informs our teaching and research we also engage in a sifting exercise: some parts of our sense of self and history find their way to the page or the classroom conversation and other parts, while likely influential, remain buried between the lines. I have written a line, edited it, deleted

${ }^{10}$ Certainly there have been many useful social analyses using standpoint theory (Harding 2004) that offer attention to how social location influences epistemology. 
it, written it again, and deleted it again a half a dozen times. It is a missing piece of this puzzle about safety, one that has complicated my thinking and opened me to the possibility of relating to students differently. Butler's words resonate here: we are "laid bare" in our vulnerability to others as we seek recognition. Rationally and intuitively, I know it belongs here on the page, but it is incredibly difficult to lay down the words and not delete them. So I will just write it. Abuse. Control through acts and threats of violence and abandonment from my mother from such an early age that I cannot remember a time before fear. Then, total rejection from her at nineteen when I came out as a lesbian, who also severed all connection my younger siblings because she feared I would "convert" them. Butler's concepts of dependency, vulnerability, and the need for recognition converge with Barrios's metaphor of being raised in the briar patch. I learned early to guard myself in a dangerous world. This is why I have held fast to my belief that safety can never truly be achieved; this is why Barrios' words resonate at the very core of my being. It has as much to do with being positioned as queer in a predominantly straight world as it does with the ways in growing up in an unsafe home and being severed from one's kin literally writes itself on the consciousness.

The research of Bessel van der Kolk et al. (1996) in the neuroscience of trauma offers a more scientific explanation. Trauma, as a form of memory gets "laid down" on the brain and produces a set of neural firing patterns that activate our cognitive alarm system: danger, danger. When presented with similar situations, neural firing patterns travel along familiar pathways that were created earlier in life. Over time these firing patterns become more and more fixed, creating what is commonly understood as a "wellworn groove" in the mind. Thus, abuse, as a form of trauma, from our primary caregivers literally encodes itself on our consciousness: human connection equals danger, dependency is a threat to self-preservation. Those who are traumatized in these ways often move through the world like a closed fist, guarded and on guard in most interpersonal relations. I see this in many queer communities, the hardened exterior, shielding our vulnerability even as it is that very vulnerability that calls us to seek recognition and identification. Because we are necessarily interconnected as social creatures, being cut off, severed, walking through the world like a closed fist, no matter how "safe" it may feel as a result of how trauma "writes" itself on the neural pathways, is actually unsafe insofar as it keeps us disconnected from others-reproducing the original injury over and over again.

This is what my students were trying teach me. They were not equating safety with social comfort nor as an absence of risk or edginess in the classroom. Their sense of feeling safe in my classroom was about interconnection and recognition: feeling connected to others as well as to the course content and activities. The course in Feminist Rhetorics and Pedagogies that spawned these conversations and my self-reflection lends itself well to a sense of interconnectivity because this course is one in which I tend to take 
more risks. ${ }^{11}$ Many of my students are not only unfamiliar with feminism, but wary of the identification: envisioning the stereotypical bra-burning, "male-bashing," angry (lesbian) woman. It has become routine for me to begin the semester explaining my own relationship to feminism: quite simply, I tell them, feminism saved me. As a teenager I was taken under the wing of several teachers who introduced me to feminist ideas and took me to independent feminist bookstores. Feminism matters to me very much, I explain, because it gave me a language to name and define the dynamics of power and control that I intuitively knew were oppressive as a young person, but had no language to name and understand. While I do not get into details, I do explain that I come from a history of abuse. My purpose in disclosing this to my students is to present feminism differently: not as "women who are against men," as some of my students may assume, and certainly not simply about sexism. Feminism is a framework for understanding the overlap of oppressions and privileges and the ways in which power and control are complex and fluid rather than fixed to particular identities or social positions. Bringing my genuine passion and experience as well as my vulnerability to the class rather than just disembodied theories lays a foundation for connection, to both me and the topic of feminism. ${ }^{12}$ Disclosing this personal history to my students takes courage because it "lays me bare" in Butler's words (and certainly, for me, it is infinitely easier to come out as a lesbian than to come out as a survivor of abuse). However, rendering myself vulnerable at the start allows for a shared recognition that is less about a common identity and more about what Butler describes as part of a shared human condition: insofar as we never fully autonomous we are all vulnerable, always dependent on others as social beings in need of recognition. ${ }^{13}$ I have come to believe that it is a shared condition of vulnerability that allows students to find points of connection to me, to other students, and to the topic of feminism and fosters the kind of reciprocity necessary for transforming student-teacher relations. Additionally, part of the work that I encourage students to do over the course of the semester involves challenging logocentric standards of what counts as "good" academic writing and normative standards of "effective" composition instruction (which often emphasize efficient, grammatically correct depersonalized writing instruction

\footnotetext{
${ }^{11}$ As a white tenured professor the option of taking risks in my professional work are made available to me with a degree of security because systemic and institutionalized forms of privilege authorize me via my racial positioning and professional status.

${ }^{12}$ There are some students who comment in course evaluations that the class seemed to get "too personal," but for the most part students indicate that this class was unique because of the community and connection it fostered. Of course, being wary of pedagogies that are ego-driven and take on a cult-like dimension with students "worshipping" the professor, I find that a degree of humility in classroom dialogues and studentteacher interchanges serves to balance reciprocity and de-center teacher authority when the tone of conversations moves toward uncritical praise.

${ }^{13}$ Importantly, while we all might share a basic vulnerability as social beings, the degree and valence of our vulnerabilities vary based on our social position in relation to power and privilege and is clearly intensified for some more than others within particular socio-political contexts.
} 
centered on audience-analysis rather than how writing might be used as a tool to transform both writer and reader). The safety students articulate as necessary to transformative pedagogies is not only having a sense of connection to people in the course, but also connection to themselves through the opportunity to experiment with alternatives that enable them to fashion more individualized rhetorical and pedagogical styles. $^{14}$

My analytical critiques of safety as well as those of other queer scholars, such as Barrios, are born of a very real sense of the world as dangerous, but absent in these critiques is the other end of the spectrum of vulnerability that Butler (2004) references in exploring what it means to be human: "we are, from the start, given over to the other... this makes us vulnerable to violence, but also to another range of touch, a range that includes the eradication of our being at the one end, and the physical support for our lives, at the other" (23). Interconnection is a birthright, and while the experience of connection is necessarily vulnerable and risky because it challenges the illusion of full autonomy, it does not have to be scripted as dangerous or unsafe.

\section{Queer Pedagogy and Forging a Livable Life}

We rarely talk about our vulnerability in academic contexts and certainly laying this on the page and admitting the degree to which my own vulnerability has influenced my work transgresses normative expectations of de-personalized scholarly writing based in logocentrism and distanced objectivity. ${ }^{15}$ But it seems to me that if we are to be genuinely transgressive, both on the page and in classrooms, we must find ways to acknowledge that which Butler (2004) insists makes life precarious: we are "laid bare from the start" and we never fully escape this (23), even as we search for ways of defining ourselves as autonomous. Although we would do well to recognize different degrees of vulnerability based on socio-historical locations and political contexts, I believe the metaphor of moving through the world like a closed fist is useful for thinking about how so many of us operate in academic contexts such as conferences, department meetings, as well as the classroom. Emphases on critique, interrogation, questioning have often been framed as necessary for staying politically viable and "edgy," but I wonder to what extent

\footnotetext{
${ }^{14}$ This course typically focuses on transformative efforts in the context of traditional classrooms because I work largely with teachers. My hope is that the sense of connection I arc towards in taking greater risks extends beyond both my classroom and their classrooms and translates into students finding their own relationship to feminism that fosters lived relations that begin to interrupt practices of power and domination.

${ }^{15}$ Logocentrism refers to the way in which reason (or logos) has been privileged in Western discourse. French theorist, Hélène Cixous has expanded the term to phallogocentrism in her work on écriture féminine to describe writing that privileges a singular focus, objectivity, linear and hierarchical organizational structures, and rationality.
} 
this insulates us from others. I am reminded of a conversation with a leading Composition and Rhetoric scholar in graduate school after I delivered a paper on the importance of being out in the classroom as a form of self-actualization. She suggested that my "identity" as a lesbian is a construct and it would be more liberating to "queer" my identity in the classroom rather than attempting to secure it via given homo/hetero categories. The point of queer theory, she explained, is to maintain our position on the margins; attempts, such as mine, to feel secure in the context of teaching would diminish our ability to interrogate normativity and truly transform pedagogy. At the time I was shocked, and of course angry, not only for being publically shamed for claiming an "identity" that did not exist, but for saying something risky, vulnerable and having summarily it dismissed.

That interchange has been crucial in the development of my own thinking about what constitutes the transgressive and the place of risk, safety, and comfort in teaching and learning contexts. Fifteen years later (and more confident in my own theoretical stance), I am not convinced that there is anything particularly transgressive or "queer" about telling a young professional that self-actualization does not matter because it is at odds with current trends in theory. ${ }^{16}$ Rather than engaging in genuine dialogue with me, theory was used divisively to elevate real knowledge over lore, new theory (post-structural theory at the time) over old theory (identity politics). There is nothing transgressive about alienating people, about furthering divisions and disconnections-creating a hierarchy between those who do "queer" work and those who do "identity politics." Critiques of identity-based politics have certainly been useful and productive in opening us to new perspectives, but to the extent that they became a way of policing the borders of queer studies, they lose much of their transformative luster. So much of queer theory has resided in the realm of critique, of dismantling, of undoing. And all of this has tremendous value in world in need of challenge and change, but shouting from the margins is not the only way to maintain an "edginess" that keeps us curious and questioning. Without a counterpart to critique, without hope and possibility, transformation can only go so far.

How do we challenge without completely alienating? This is a question educators must return to again and again, for to become too wedded to the solidity of our knowledge reproduces power structures in pedagogical interactions. I maintain a passion for critiquing over-simplistic notions of safety and maternal metaphors for female teachers, particularly those which reproduce the "comfort" or safety of those already in privileged positions; however, I am not so tied to my belief system that I have lost my

\footnotetext{
${ }^{16}$ David Halerpin (2003) offers an eloquent discussion of the normalization of queer theory as it has become institutionalized and the disconnection between the theory and the quotidian lives of lesbians and gay men. David Eng, Judith Halberstam and José Esteban Muñoz (2005) also examine how queer theory tends to reproduce white, male normativity through lack of intersectional analyses that address the complexity of sexuality in relation to other social positions.
} 
ability to be self-reflexive. Teaching and writing about pedagogy are not mere intellectual exercises. They are, for many of us, a microcosm of life, of living in relation to others in the context of power, privilege, and hope for change. A truly transgressive pedagogy creates the conditions in which people can begin to pursue more meaningful directions of what makes a life a livable life, and central to that "livability" is acknowledging interconnection.

There is another way to maintain an "edginess" that keeps us arcing towards the transgressive rather than assimilation into the normative. Placing our dependency, our vulnerability more squarely at the center of teaching and research is incredibly edgy because we are forced into the unknown. ${ }^{17}$ It is a shaky kind of place to be in, and of course we do not often like this as intellectuals who have been trained to appreciate the firmness of the known. ${ }^{18}$ Given the right conditions and the right moment, there is a promise that something more meaningful, some different or deeper form of connection can be forged when we let go of certainties that keep us locked in and away from a whole realm of perspectives that simply are not possible when moving through the world as closed fists: self-certain and disconnected from others.

\section{References}

Barrios, Barclay. 2004. "Of Flags: Online Queer Identities, Writing Classrooms, and Action Horizons." Computers and Composition 21(3): 341-61.

\footnotetext{
${ }^{17}$ I do not advocate this in all teaching contexts nor for all teachers because we are not all positioned as equals. Questions of authority, risk, and vulnerability must take into account the ways in which we each occupy multiple positions in relation to power and privilege which necessarily affects the degree to which we are rendered more or less vulnerable before we ever enter the classroom or other sites within educational institutions. Equally important, I want to emphasize again that power does not simply reside in the hands of the teacher. In the face of hostility and aggression from students (and, in many cases unsupportive and/or hostile administrators), it is important to recognize danger as danger and maintain distance that allows for protection and self-preservation.

${ }^{18}$ Freire (Shor and Freire 1987) argues for a similar approach to the unknown in arguing for the necessity of humility: "Humility does not flourish in people's insecurities but in the insecure security of the more aware, and thus this insecure security is one of the expressions of humility, as is uncertain certainty, unlike certainty, which is excessively sure of itself" (40). Importantly, Feire's vision of humility is not akin to meekness or docility; these are characteristics that have been too often expected of marginalized peoples and would not be transgressive of normative subjectivities imposed on "others." Always cognizant of the locations from which we teach and speak, the degree to which we invoke humility or attempt to stand on "shaky ground" is contingent on the extent to which our positions already carry privilege and power.
} 
Bannerji, Himani. 1995. Thinking Through: Essays on Feminism, Marxism and AntiRacism. Toronto: Women's Press.

Brown, Robert D. and Carl A. Happold. 2002. Campus Climate and Needs Assessment Study for Gay, Lesbian, Bisexual, and Transgender (GLBT) Students at the University of Nebraska-Lincoln: Moving Beyond Tolerance Toward Empowerment. Lincoln: The University of Nebraska-Lincoln.

Butler, Judith. 1997. The Psychic Life of Power: Theories in Subjection. Palo Alto, CA: Stanford University Press.

Butler, Judith. 1999. Gender Trouble: Feminism and the Subversion of Identity. New York: Routledge.

Butler, Judith. 2004. Undoing Gender. New York: Routledge.

Butler, Judith. 2005. Giving an Account of Oneself. New York: Fordham University Press.

Cixous, Hélène. 1976. “The Laugh of the Medusa.” Trans. Keith Cohen and Paula Cohen. Signs 1 (4): 875-93.

Eng, David L, Judith Halberstam and José Esteban Muñoz. 2005. "What's Queer about Queer Studies Now?” Social Text 23 (3-4): 1-17.

Fisher, Bernice. 2001. No Angel in the Classroom: Teaching through Feminist Discourse. Lanham, Maryland: Rowman and Littlefield Publishers.

Foss, Sonja and Cindy Griffin. 1995. "Beyond Persuasion: A Proposal for an Invitational Rhetoric." Communication Monographs 62: 2-18.

Fox, Catherine. 2007. "From Transaction to Transformation: (En)Countering White Heteronormativity in 'Safe Spaces.”' College English 69 (5): 496-511.

Fox, Catherine. 2010. "(Un)Covering Normalized Gender and Race Subjectivities in LGBT 'Safe Spaces.”' Feminist Studies 36 (3): 629-651.

Freire, Paulo. 1970. Pedagogy of the Oppressed. New York: Continuum. 
Gay, Lesbian \& Straight Education Network. "GLSEN Safe Space: A How-To Guide for Starting an Allies Program.” GLSEN. 25 July 2012. http://www.glsen.org/cgibin/iowa/all/library/record/1641.html.

Gearhart, Sally Miller. 1979. "The Womanization of Rhetoric." Women's Studies International Quarterly 2: 195-201.

Greenbaum, Andrea. 2002. Emancipatory Movements in Composition: The Rhetoric of Possibility. Albany, NY: State University of New York Press.

Halerpin, David. 2003. “The Normalization of Queer Theory.” Journal Of Homosexuality 45: 339-343.

Hall, Stuart. 1996. “The Problem of Ideology: Marxism without Guarantees.” In Stuart Hall: Critical Dialogues in Cultural Studies, David Morely and Kuan-Hsing Chen, editors. 25-46. New York: Routledge.

Harding, Sandra, editor. 2004. The Feminist Standpoint Theory Reader: Intellectual and Political Controversies. New York: Routledge.

Hooks, Bell. 1994. Teaching to Transgress: Education as the Practice of Freedom. New York: Routledge.

Jarratt, Susan. 2000. "Feminist Pedagogy." In A Guide to Composition Pedagogies, Gary Tate, Amy Rupiper, and Kurt Shick, editors, 113-131. New York: Oxford University Press.

Jarratt, Susan. 2003. "Feminism and Composition: A Case for Conflict." In Feminism and Composition, Gesa Kirsch, Faye Spencer Maor, Lance Massey, Lee NickosonMassey, and Mary Sheridan, editors, 263-280. Boston: Bedford/St. Martin's Press.

Kishimoto, Kyoko and Mumbi Mwangi. 2009. "Critiquing the Rhetoric of 'Safety' in Feminist Pedagogy: Women of Color Offering an Account of Ourselves." Feminist Teacher 19 (2): 87-102.

Kopelson, Karen. 2002. "Dis/Integrating the Gay/Queer Binary: 'Reconstructed Identity Politics' for a Performative Pedagogy." College English 65 (1): 17-35. 
Socialist Studies / Études socialistes Volume 9 (1), Spring 2013

Noddings, Nel. 1984. Caring: A Feminine Approach to Ethics and Moral Education. Berkeley: University of California Press.

Ng, Roxana. 1993. “'A Woman out of Control': Deconstructing Sexism and Racism in the University." Canadian Journal of Education 18 (3): 189-205.

Rankin, Susan. 2004. Iowa State University Campus Climate Assessment Project. Ames, IA: Iowa State University.

Shor, Ira and Paulo Freire. 1987. "Do First-World Students Need Liberating?" In A Pedagogy for Liberation: Dialogues on Transforming Education, Ira Shor, editor, 121-141. Westport, CT: Bergin \& Garvey.

Van der Kolk, Bessel, Alexander McFarlane, and Lars Weisaeth, editors. 1996. Traumatic Stress: The Effects of Overwhelming Experience on Mind, Body, and Society. New York: The Guilford Press.

Warner, Michael. 1991. "Fear of a Queer Planet.” Social Text 29: 3-17. 